\section{Factors associated to infant mortality in Sub-Saharan Africa}

\author{
Pablo Viguera Ester, ${ }^{1}$ Alberto Torres, ${ }^{2}$ \\ José M. Freire, ${ }^{3}$ Valentín Hernández, ${ }^{1}$ \\ Ángel Gil ${ }^{1}$ \\ 1Department of Preventive Medicine \\ and Public Health, Immunology \\ and Microbiology, University Rey Juan \\ Carlos; ${ }^{2}$ Department of Preventive \\ Medicine, University of Murcia; \\ ${ }^{3}$ Department of International Health, \\ Institute of Health Carlos III, Ministry \\ of Health and Consumption, Spain
}

\section{Abstract}

Half of the 10 million children who die annually in the world are from Sub-Saharan Africa (SSA). The reasons are known, but lack of will and resources avoid the development of sustainable policies. Associated factors to the high infant mortality rate (IMR) in SSA have been investigated in this research. An ecological multi-group study was designed comparing rates within SSA. The dependent variable is the IMR and health services, economic and development indicators are the independent variables. Information and data sources were WHO, World Bank, UNICEF and UNDP (19972007). IMR mean value is 92.2 (per 1000 live births) and a relationship with several of the factors could be observed. In the bi-variate analysis direct relationship was observed with maternal mortality rate and an inverse relationship was observed with prenatal care coverage, births assisted by skilled health personnel, gross national income per capita, per capita government expenditure on health, social security expenditure, adult literacy rate, net primary school enrolment rate, population with access to safe drinking water (in urban and rural areas) and with population with access to basic sanitation in rural areas. In the multi-variate analysis IMR had an inverse relationship with children under 5 years with diarrhoea who receive oral re-hydration, with social security expenditure as percentage of general government expenditure on health and with per capita government expenditure on health. The situation in SSA would change if their inhabitants received education and information to demand more equitable polices and better investments from their governments.

\section{Introduction}

It is estimated that half of the 10 million children under 5 years old, who die every year in the world (1000 child deaths per hour) are in Sub-Saharan Africa (SSA). ${ }^{1}$ Most of these children could have survived if they had access to basic services and to simple, inexpensive and easily implemented interventions.

The causes of high infant mortality rate (IMR) in SSA are well known. Some such as malaria disappeared from southern Europe only in the 1960 s, while vaccine-preventable diseases (diphtheria, tetanus, whooping cough, polio or measles) disappeared later though not entirely. Children in underdeveloped countries are not decimated by exotic diseases but rather by common and frequent problems. Around 1.5 million children die from drinking unsafe water or the lack of access to water for personal hygiene and poor access to basic sanitation. ${ }^{2}$ This means that the improvement of some factors could reduce the IMR. $^{3}$

Children born in SSA today have a life expectancy of 51 years, and almost $10 \%$ of them die in the first year of life. One hundred fifty five out of every 1000 children born today do not reach the age of five. IMR is particularly high in the first month of life, with a neonatal mortality of 40 out of every 1000 live births. ${ }^{4}$ The main causes are, in order of importance, neonatal causes $(26 \%)$, child pneumonia (21\%), malaria (18\%), diarrhoea (16\%), HIV/AIDS (6\%), measles (5\%) and accidents (2\%). However there are differences in SSA between countries in the proportion of deaths attributed to HIV infection (probably due to poor records) and malaria (different endemic patterns in these countries). ${ }^{5}$

Achieving the fourth Millennium Development Goal (MDG 4), which requires reducing in two thirds the children under 5 years old mortality rate, between 1990 and 2015 , involves reducing it from 9.7 million in 2006 to less than 5 million in $2015 .^{6}$ It is clear that reaching these goals will require political participation, resources and suitable strategies at a level that has never before been seen.

The World Health Organization (WHO), in collaboration with UNICEF, implemented the Integrated Management of Childhood Illnesses (IMCI) strategy in the mid 1990s. ${ }^{7}$ The proposal is to reduce child mortality. For this the IMCI has set in motion preventive and curative interventions at the family, community and institutional level. A number of studies have demonstrated that this strategy is not only effective, ${ }^{8}$ but also efficient. ${ }^{9}$

The objective of this study is determining different types of factors (health services, economic and development factors) associated
Correspondence: Dr. Pablo Viguera Ester, Department of Preventive Medicine and Public Health, Immunology and Microbiology, University Rey Juan Carlos, Avenida de Atenas s/n 28922 Alcorcón, Madrid, Spain.

Tel. +34.649.423092.

E-mail: pablo.viguera@urjc.es

Key words: infant mortality, Sub-Saharan Africa, associated factors, IMCI, education, basic infrastructure.

Contribution: PVB, main author, conceived, designed and coordinated the study; AT, JMF, AG, study supervision and coordination; $\mathrm{VH}$, study design participation and statistical analysis accomplishment. All authors read and approved the final manuscript.

Conflict of interest: the authors report no conflicts of interest.

Received for publication: 3 November 2010. Accepted for publication: 10 June 2011.

This work is licensed under a Creative Commons Attribution NonCommercial 3.0 License (CC BYNC 3.0).

(C) Copyright P.V. Ester et al., 2011

Licensee PAGEPress, Italy

Journal of Public Health in Africa 2011; 2:e27

doi:10.4081/jphia.2011.e27

with the high IMR in SSA countries, by means of statistical models and with the latest data obtained from the main international information sources (WHO, World Bank, UNICEF and UNDP).

\section{Materials and Methods}

An analytic ecological multi-group study ${ }^{10}$ was designed to compare rates between many regions during a single period. In this specific case each SSA country is used as an analysis unit. The 47 countries selected are: Angola, Benin, Botswana, Burkina Faso, Burundi, Cameroon, Cape Verde, Central African Republic, Chad, Comoros, Congo, Ivory Coast, D.R. Congo, Djibouti, Equatorial Guinea, Eritrea, Ethiopia, Gabon, Gambia, Ghana, Guinea, Guinea Bissau, Kenya, Lesotho, Liberia, Madagascar, Malawi, Mali, Mauricio, Mozambique, Namibia, Niger, Nigeria, Rwanda, Sao Tome and Principe, Senegal, Seychelles, Sierra Leona, Somalia, South Africa, Sudan, Swaziland, Tanzania, Togo, Uganda, Zambia and Zimbabwe.

The result/dependent variable is the IMR (per 1000 live births) obtained from WHO (World Health Statistics (WHS) 2007).

The independent variables are as follows. 


\section{Health services indicators}

Maternal mortality rate (per 100.000 live births): WHO (WHS-2007).

Prenatal care coverage (\%): UNICEF (Information by Country (IbC); statistics).

Births attended by skilled health personnel (\%): WHO (WHS-2007).

Children under 5 years of age sleeping under insecticide-treated nets (\%): WHO (WHS-2007). Except Equatorial Guinea, Ethiopia, Guinea, Mali, Namibia: UNICEF (IbC; statistics).

Children under 5 years of age with diarrhoea receiving oral rehydration therapy (\%): WHO (WHS-2007) Except: Angola, Botswana, Burundi, Central African Republic, Comoros, D.R. Congo, Equatorial Guinea, Ethiopia, Gambia, Guinea- Bissau, Sao Tome and Principe, Sierra Leona, Sudan, Swaziland, Togo: UNICEF (IbC; statistics).

Children under 5 years of age with acute respiratory infections (ARI) taken to facility (\%): WHO (WHS 2007). Except: Angola, Botswana, Burundi, Central African Republic, Comoros, D.R. Congo, Equatorial Guinea, Gambia, Guinea- Bissau, Liberia, Sao Tome and Principe, Sierra Leona, Sudan, Swaziland, Togo: UNICEF (IbC; statistics).

\section{Economic indicators}

Gross national income (GNI) per capita (current US Dollars): WB (World Development Indicators-2007).

Government expenditure on health as percentage of the general government expenditure (\%): WHO (WHS-2007).

Per capita government expenditure on health
(PPP): WHO (WHS-2007).

Social security expenditure on health as percentage of the general government expenditure on health (\%): WHO (WHS-2007).

Out-of-pocket expenditure as percentage of the private expenditure on health (\%): WHO (WHS-2007).

\section{Development indicators}

Adult literacy rate (\%): WHO (WHS-2007). Except Congo, Gabon, Mozambique, Nigeria, Sao Tome and Principe and Zimbabwe. UNDP (Human Development Report 2007-2008).

Net primary school enrollment rate (\%): UNDP-2005.

Population with sustainable access to safe drinking water in urban areas (\%): WHO (WHS-2007).

Population with sustainable access to safe drinking water in rural areas (\%): WHO (WHS2007).

Population with sustainable access to basic sanitation in urban areas (\%): WHO (WHS2007).

Population with sustainable access to basic sanitation in rural areas (\%): WHO (WHS2007).

All this information was used to first provide a descriptive analysis of the variables. The normal distribution was checked by applying the Kolmogorov-Smirnov test. The degree of the relation of the IMR with the remaining variables was studied by means of Pearson's correlations ( $r$ ) in the bi-variate analysis and, finally, a multi-variate analysis was performed by applying a linear regression $\left(\mathrm{R}^{2}\right)$ to obtain the factors associated to IMR. A value of $\mathrm{P}<0.05$ was considered significant. SPSS 14.0 (descriptive analysis) and Stata 10.0 (correlations and regression) statistical software packages were used to process and analyze the data.

\section{Results}

The descriptive analysis is presented in Table 1. The mean of the IMR is 92.19 with a standard deviation of 34.69 .

About the health services indicators, $4.57 \%$ of children under 5 years of age sleep under insecticide-treated nets, $50 \%$ of them receive oral rehydration therapy when they have diarrhoea, and $43.33 \%$ are taken to facility when ARIs are suspected. In relation to the maternal and perinatal data, there is a mean maternal mortality rate of 853.42 , a percentage of prenatal care coverage of $77.16 \%$ and a percentage of births attended by skilled personnel of $53.39 \%$.

The economic indicators show a GNI per capita of $1445.22 \$$ (current US\$) and a per capita government expenditure on health of $76.78 \$$ (PPP). The government expenditure on health as percentage of the general government expenditure is $9.78 \%$ and the social security expenditure on health as percentage of the general government expenditure on health was $3.21 \%$. However the out-of-pocket expenditure as percentage of the private expenditure on health is $77.77 \%$.

Table 1. Mean, range and standard deviation of indicators selected.

\begin{tabular}{|c|c|c|c|c|}
\hline $\begin{array}{l}\text { ( } \\
\text { co } \\
\text { av }\end{array}$ & $\begin{array}{c}\mathrm{N} \\
\text { (number of } \\
\text { countries with } \\
\text { ivailable data) }\end{array}$ & Mean & $\begin{array}{l}\text { Range } \\
\text { (lowest } \\
\text {-highest } \\
\text { values) }\end{array}$ & $\begin{array}{l}\text { Standard } \\
\text { deviation }\end{array}$ \\
\hline Infant mortality rate & 47 & 92.19 & $(12-165)$ & 34.69 \\
\hline $\begin{array}{l}\text { Health services indicators } \\
\text { Children under } 5 \text { years of age sleeping under insecticide-treated nets (\%) } \\
\text { Children under } 5 \text { years of age with diarrhoea receiving oral rehydration therapy (\%) } \\
\text { Children under } 5 \text { years of age with ARI taken to facility (\%) } \\
\text { Maternal mortality rate (per 100,000 live births) } \\
\text { Prenatal care coverage (\%) } \\
\text { Births attended by skilled health personnel (\%) }\end{array}$ & $\begin{array}{l}35 \\
41 \\
41 \\
45 \\
43 \\
46\end{array}$ & $\begin{array}{r}4.57 \\
49.95 \\
43.32 \\
835.42 \\
77.16 \\
53.39\end{array}$ & $\begin{array}{l}(0-36) \\
(7-89.1) \\
(11.8-75.3) \\
(24-2000) \\
(28-99) \\
(6-99)\end{array}$ & $\begin{array}{r}7.18 \\
19.50 \\
15.69 \\
440.57 \\
17.88 \\
21.83\end{array}$ \\
\hline $\begin{array}{l}\text { Economic indicators } \\
\text { GNI per capita (current US\$). } \\
\text { Per capita government expenditure on health (PPP) } \\
\text { Government expenditure on health as percentage of the general government expenditure (\%) } \\
\text { Social security expenditure on health as percentage of the general government expenditure on health (\%) } \\
\text { Out-of-pocket expenditure as percentage of the private expenditure on health (\%) }\end{array}$ & $\begin{array}{l}44 \\
46 \\
46 \\
35 \\
45\end{array}$ & $\begin{array}{r}1445.22 \\
76.78 \\
9.78 \\
3.21 \\
77.77\end{array}$ & $\begin{array}{l}(140-8650) \\
(4-317) \\
(2.3-28.8) \\
(0-14.7) \\
(17.2-100)\end{array}$ & $\begin{array}{r}2174.62 \\
106.86 \\
4.64 \\
6.25 \\
27.01\end{array}$ \\
\hline $\begin{array}{l}\text { Development indicators } \\
\text { Adult literacy rate (\%) } \\
\text { Net primary school enrollment rate (\%) } \\
\text { Population with sustainable access to safe water in urban areas (\%) } \\
\text { Population with sustainable access to safe water in rural areas (\%) } \\
\text { Population with sustainable access to basic sanitation in urban areas (\%) } \\
\text { Population with sustainable access to basic sanitation in rural areas (\%) }\end{array}$ & $\begin{array}{l}41 \\
39 \\
47 \\
47 \\
46 \\
47\end{array}$ & $\begin{array}{l}61.87 \\
71.07 \\
83.23 \\
54.74 \\
52.84 \\
30.34 \\
\end{array}$ & $\begin{array}{l}(19-91.8) \\
(33-99) \\
(32-100) \\
(11-100) \\
(24-95) \\
(3-100)\end{array}$ & $\begin{array}{l}20.71 \\
18.16 \\
14.60 \\
19.43 \\
15.04 \\
20.59\end{array}$ \\
\hline
\end{tabular}

ARI, acute respiratory infections; GNI, gross national income; PPP, Per capita government expenditure on health. 
Table 2. Bi-variate analysis (correlation) between infant mortality rate and the selected indicators.

\begin{tabular}{|c|c|c|c|}
\hline Indicator & $\begin{array}{l}\text { Pearson correlation } \\
\text { index (r) }\end{array}$ & $\begin{array}{l}\text { Significance } \\
\text { (two-sided) }\end{array}$ & $\begin{array}{l}\text { N } \\
\text { (number of } \\
\text { countries with } \\
\text { available data) }\end{array}$ \\
\hline Infant mortality rate & 1 & & 47 \\
\hline $\begin{array}{l}\text { Health service indicators } \\
\text { Children under } 5 \text { years of age sleeping under insecticide-treated nets (\%) } \\
\text { Children under } 5 \text { years of age with diarrhoea receiving oral rehydration therapy (\%) } \\
\text { Children under } 5 \text { years of age with ARI taken to facility (\%) } \\
\text { Maternal mortality rate (per 100,000 live births) } \\
\text { Prenatal care coverage (\%) } \\
\text { Births attended by skilled health personnel (\%) }\end{array}$ & $\begin{array}{r}-0.23 \\
-0.39 \\
-0.05 \\
0.67 \\
-0.46 \\
-0.55\end{array}$ & $\begin{array}{l}>0.05 \\
>0.05 \\
>0.05 \\
<0.01 \\
<0.01 \\
<0.01\end{array}$ & $\begin{array}{l}35 \\
41 \\
41 \\
45 \\
43 \\
46\end{array}$ \\
\hline $\begin{array}{l}\text { Economic indicators } \\
\text { GNI per capita (current US\$). } \\
\text { Per capita government expenditure on health (PPP) } \\
\text { Government expenditure on health as percentage of the general government expenditure (\%) } \\
\text { Social security expenditure on health as percentage of the general government expenditure on health (\%) } \\
\text { Out-of-pocket expenditure as percentage of the private expenditure on health (\%) }\end{array}$ & $\begin{array}{r}-0.41 \\
-0.53 \\
-0.06 \\
-0.41 \\
0.19\end{array}$ & $\begin{array}{l}<0.01 \\
<0.01 \\
>0.05 \\
<0.05 \\
>0.05\end{array}$ & $\begin{array}{l}44 \\
46 \\
46 \\
35 \\
45 \\
\end{array}$ \\
\hline $\begin{array}{l}\text { Development indicators } \\
\text { Adult literacy rate } \\
\text { Net primary school enrollment rate (\%) } \\
\text { Population with sustainable access to safe drinking water in urban areas (\%) } \\
\text { Population with sustainable access to safe drinking water in rural areas (\%) } \\
\text { Population with sustainable access to basic sanitation in urban areas (\%) } \\
\text { Population with sustainable access to basic sanitation in rural areas (\%) }\end{array}$ & $\begin{array}{l}-0.52 \\
-0.4 \\
-0.47 \\
-0.5 \\
-0.2 \\
-0.42\end{array}$ & $\begin{array}{l}<0.01 \\
<0.05 \\
<0.01 \\
<0.01 \\
>0.05 \\
<0.01\end{array}$ & $\begin{array}{l}41 \\
39 \\
47 \\
47 \\
46 \\
47\end{array}$ \\
\hline
\end{tabular}

ARI, acute respiratory infections; GNI, gross national income; PPP, Per capita government expenditure on health.

The development indicators show an adult literacy rate of $62 \%$ and a net primary school enrollment rate of $71 \%$. In urban areas the percentage of population with sustainable access to safe drinking water is $83.23 \%$ and the percentage of population with sustainable access to basic sanitation is $52.84 \%$. However these values are lower in rural areas, where $54.74 \%$ of the population has access to safe drinking water and $30.34 \%$ of the population has access to basic sanitation.

\section{Correlations}

This study is presented in Table 2.

\section{Health services indicators}

Direct and strong relationship between the IMR and the maternal mortality rate (Correlation coefficient $(r)=0.67 ; \mathrm{P}<0.01$ ) and an inverse and strong relationship with prenatal care coverage $(\mathrm{r}=-0.46 ; \mathrm{P}<0.01)$ and with births attended by a skilled health personnel $(\mathrm{r}=-0.55 ; \mathrm{P}<0.01)$ is observed.

\section{Economic indicators}

Direct relationship is observed with the outof-pocket expenditure as percentage of the private expenditure on health, however it is weak and not significant $(\mathrm{r}=0.19 ; \mathrm{P}>0.05)$. The relationship is inverse with the remaining indicators. It is significant and strong for the GNI per capita $(\mathrm{r}=-0.41 ; \mathrm{P}<0.01)$, per capita government expenditure on health $(\mathrm{r}=-0.53 ; \mathrm{P}<0.01)$ and the social security expenditure as percentage of the general government expenditure on health $(\mathrm{r}=-0.41 ; \mathrm{P}<0.05)$.

Table 3. Linear regression model between infant mortality rate and the correlated indicators.

\begin{tabular}{llccc} 
& $\begin{array}{l}\text { Regression } \\
\text { coefficient }\left(\mathrm{R}^{2}\right)\end{array}$ & $\mathrm{t}$ & $\mathrm{P}>\mathrm{t}$ & $\begin{array}{c}\text { [95\% confidence } \\
\text { interval }]\end{array}$ \\
$\begin{array}{l}\text { Children under } 5 \text { years of age with } \\
\text { diarrhoea receiving oral rehydration } \\
\text { therapy (\%) }\end{array}$ & -0.57 & -2.98 & $\mathrm{P}<0.01$ & {$[-0.986--0.16]$} \\
$\begin{array}{l}\text { Social security expenditure on health } \\
\text { as percentage of the general } \\
\text { government expenditure } \\
\text { on health (\%) }\end{array}$ & -2.64 & -3.63 & $\mathrm{P}<0.01$ & {$[-4.2--1.08]$} \\
$\begin{array}{l}\text { Per capita government expenditure } \\
\text { on health (PPP) }\end{array}$ & -0.09 & -2.32 & $\mathrm{P}<0.05$ & {$[-0.165--0.006]$} \\
\begin{tabular}{l} 
Constant \\
\hline
\end{tabular} & 134.45 & 10.83 & 0.000 & {$[107.82-161.08]$} \\
\hline
\end{tabular}

Adjusted $\mathrm{R}^{2}$ value $=0.54$.

\section{The development indicators}

The development indicators show inverse relationships in all cases, and are significant and strong for the adult literacy rate $(\mathrm{r}=-0.52$; $\mathrm{P}<0.01)$, net primary school enrollment rate* $(\mathrm{r}=-0.4 ; \mathrm{P}<0.05)$, the population with sustainable access to safe drinking water in urban and rural areas $(\mathrm{r}=-0.47 ; \mathrm{P}<0.01$ and $\mathrm{r}=-0.5$; $\mathrm{P}<0.01$ ) and the population with sustainable access to basic sanitation in rural areas $(r=-$ $0.42 ; \mathrm{P}<0.01)$

\section{Linear regression}

The data resulting from the multi-variant analysis are presented in Table 3. A linear regression model was applied, resulting in a model using the factors examined in this study to explain the IMR. The factors presenting statistically significant $(\mathrm{P}<0.05)$ regression coefficient $\left(\mathrm{R}^{2}\right)$ were selected in this case.

Three factors inversely related to the IMR were found for this study, which are children under 5 years of age with diarrhoea receiving oral rehydration therapy $\left(\mathrm{R}^{2}=-0.57 ; \mathrm{P}<0.01\right)$, the social security expenditure on health as percentage of the general government expenditure on health $\left(\mathrm{R}^{2}=-2.64 ; \mathrm{P}<0.01\right)$ and the per capita government expenditure on health $\left(R^{2}=-0.09 ; P<0.05\right)$.

*The net primary school enrollment rate has been included due to its statistically significant $r$ of virtually 0.4 . It also shows one of the lowest $N$, therefore further data would probably provide a higher strength. 


\section{Discussion}

The classically used health indicators exhibited their increasingly close relations with the social and economic indicators. ${ }^{11}$ This relation has transformed them into social development indicators. The IMR in particular is considered one of the most useful indicators of health status, not only in children between birth and 1 year of age, but also of the whole population and the socioeconomic conditions under which they live. In addition, the IMR is a sensitive indicator of the availability, use and effectiveness of health care, particularly perinatal care. ${ }^{12}$

The bivariate analysis indicated relationships of more factors with IMR. The strong and direct correlation between maternal mortality and IMR is striking, though it is not surprising given that in SSA countries, the mother is a fundamental basis for the survival of her children, especially in their first years of life. The role of women in SSA is very important for the future development of this continent. Women are the main pillars of families ${ }^{13}$ and, therefore, of the society that will be formed by the coming generations. Education of women reduces the IMR and increases the general health of the population, as has been observed in the example of Kerala and Neuquen. ${ }^{14}$ Economic factors also show a strong inverse correlation. The out-of-pocket expenditure as a percentage of the private expenditure on health is striking because even though the correlation is not statistically significant, it is the only factor presenting a positive value (direct correlation) with regard to the IMR. This could support what has been published in a number of studies ${ }^{15}$ in relation to the financing system's inequity and inefficacy. However, it cannot be concluded that there is a relationship with the available data. The inverse correlations with development factors, especially the adult literacy rate and the net primary school enrolment rate, are also very strong. The efforts of many organisations to provide basic training, especially for mothers, give SSA countries a more hopeful future since, as has been observed, more education of the mothers reduces not only the IMR, but also morbidity and misuse of health services. ${ }^{16}$

This study revealed, in the multi-variate analysis, three factors associated with the IMR: a higher social security expenditure on health as a percentage of the general government expenditure on health, a higher per capita government expenditure on health and a higher number of children under 5 years of age with diarrhoea receiving oral rehydration therapy indicate a lower IMR. The first two factors are key for health policy planning. It has been demonstrated in several studies that equal access to health services is increased in Social
Security Systems, ${ }^{17}$ resulting in a larger number of people who are receiving appropriate health care, especially children and mothers. There is a new perspective on the development of health systems based on Social Security financing in several African countries. They are showing an improvement in their sanitary situation as well as in their development situation, and, undoubtedly, these facts will have repercussions in their economies. ${ }^{18}$ It is surprising in this multivariate analysis model that no association was found with other indicators traditionally associated with high IMR, as sustainable access to safe drinking water and basic sanitation. Its association is well documented ${ }^{19}$ but since all countries have relatively, high level of access (83.23\%) with relatively small variation among countries (range 32100) data used may have failed to show any association in this analysis.

Finally, when assessing this data it is necessary to bear in mind several considerations. The data have been obtained from four different databases: WHO, WB, UNICEF and UNDP, and it may be problematic using them in combination; however, data collection methodologies are similar and therefore this effect on the final result is probably not relevant. In some cases, the information sources are based on estimates, thereby providing only a close to reality approximate of the situations in these countries. Furthermore, the lack of a great deal of this data makes the analysis less precise (though the lack of data also provides considerable information); nevertheless, the existing data provide a first step for planning future studies. The inherent limitations of ecological studies must be taken into account. The central problem is the one referred to by Selvin ${ }^{20}$ as the ecological fallacy, but classical examples, such as the Snow ${ }^{21}$ and Farr ${ }^{22}$ studies about cholera disease, show the advantages of this type of research, in spite of the important limitations in the detailed biological knowledge of this disease.

It can be said that it is necessary to improve information and recording systems in SSA countries. The situation in these countries cannot be improved if the problems and actual difficulties are not known. In addition, after conducting the study, it is striking that the factors associated with and correlated with the high IMR are the lack of basic infrastructures (water and sanitation), the lack of basic formal education (especially of women), the lack of an effective and efficient health system and the lack of a good government that is concerned about the social protection of its citizens and is able to invest in their health.

\section{References}

1. UNICEF. State of the World's Children 2008. Child Survival. Executive Summary. New York. December 2007. Accessed on 11/12/2010. Available from: http://www.unicef.org/spanish/sowc08/ docs/sowc08_execsummary-sp.pdf

2. Black RE, Morris SS, Bryce J. Where and why are 10 million children dying every year? Lancet 2003; 361: pp 2226-34. [Accessed: 11/12/2010]. Available from: http://www.afro.who.int/cah/documents/tra ining/lancet/child_survival_1.pdf

3. Ahmad OB, Lopez AD, Inoue M. The decline in child mortality: a reappraisal. Bull World Health Organ 2000;78:1175-91.

4. WHO. World Health Statistics 2008. Geneva. May 2008. Accessed on 12/12/2010. Available from: http://www. who.int/whosis/whostat/IN_WHS08_Full.p df

5. Bryce J, Boschi-Pinto C, Shibuya K, et al. WHO estimates of the causes of death in children. Lancet 2005;365:1147-52.

6. UNICEF. State of the World's Children 2008. Child Survival. Executive Summary. New York. December 2007. Accessed on 13/12/2010. Available from: http://www. unicef.org/spanish/sowc08/docs/sowc08_e xecsummary-sp.pdf

7. Gove S. Integrated Management of childhood illness by outpatient health workers: technical basis and overview. Bull World Health Organ 1997;75(Suppl.1):7-24.

8. Al Fadil SM, Abd Alrahman SH, Cousens S, et al. Integrated Management of Childhood Illness strategy: compliance with referral and follow-up recommendations in Gezira State, Sudan. Bull World Health Organ 2003;81:708-716.

9. Adam T, Manzi F, Armstrong J, et al. Does the Integrated Management of Childhood Illness cost more than routine care? Results from the United Republic of Tanzania. Bull World Health Organ 2005; 83:369-377.

10. Morgenstern H. Uses of ecologic analysis in epidemiologic research. Am J Public Health 1982;72:1336-44.

11. yçaguer LC, Macho ED. [Infant mortality and health and social conditions in the Americas. A correlation study] [Article in Spanish]. Rev Saude Publica 1990;24:47380.

12. WHO. Development of indicators for monitoring progress towards health for all by the year 2000. Geneva. 1981. Accessed on 14/12/2010. Available from: http:/whqlibdoc.who.int/publications/9241800046.pdf

13. Solsona M, Fonseca MC, Merino M. Cambio demográfico, migración y salud reproductiva: el papel de las mujeres sene- 
galesas en la constitución de las familias. Proc. Symposium Género y Salud: Aprender para Cooperar, Barcelona, Spain. Quaderns CAPS 2003;31:68-80. Accessed on 14/12/2010. Available from: http://www. ced.uab.is/publicacions/PapersPDF/Text22 0 .pdf

14. Fernández M. Kerala y Neuquén: dos oasis de desarrollo humano. Arch Argent Pediatr 2003;101:146-52.

15. Torres AC, Knaul FM. Determinantes del gasto de bolsillo en salud e implicaciones para el aseguramiento universal en México: 1992-2000. Funsalud. Caleidoscopio de la salud 2003;3:209-25. Accessed on
15/12/2010. Available from: http://www.funsalud.org.mx/CASEsalud/caleidoscopio/15\%20DeterminantesDelGasto.pdf

16. Tafani R, Gaspio N, Maldonado R. Economía, Educación y Salud Materno Infantil. Rev Salud Pública 2005;9:24-52.

17. Céspedes-Londoño JE, Jaramillo-Pérez I, Castaño-Yepes RA. Impacto de la reforma del sistema de seguridad social sobre la equidad en los servicios de salud en Colombia. Cad Saúde Pública 2002; 18:1003-24.

18. Booysen F. Social grants as safety net for HIV/AIDS-affected households in South Africa. SAHARA J 2004;1:45-56.
19. Bryce J, Arifeen S, Pariyo G, et al. Reducing child mortality: can public health deliver? Lancet 2003;362:159-64.

20. Selvin H. Durkheim's suicide and problems of empirical research. Am J Sociol 1958;63:607-19.

21. Snow J. On the mode of communication of cholera. 2nd ed. London: J. Churchill, 1855. Reprinted as Snow on cholera. New York, NY, USA. The Commonwealth Fund, 1956.

22. Farr W. Report on the mortality of cholera in England in 1848-1849. Her Majesty's Stationery Office Publ., London, UK, 1852. 